\author{
성별 특이 소 혈청이 세포 배양에 미치는 영향

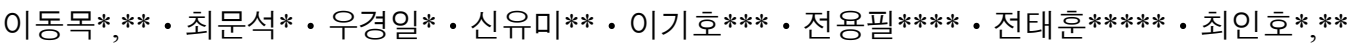 \\ 영남대학교 생명공학부*, 소유전체연구소재은행**, 을지대학교 생화학교실***, 성신여자대학교 생물학과****, \\ 고려대학교 생명과학대학*****
}

\title{
Effect of Gender-specific Bovine Serum Supplemented Medium on Cell Culture
}

\author{
Dong Mok Lee*,*, Moon Seok Choi*, Gyung Il Woo*, Yu Mi Shin**, Ki Ho Lee***, Yong Pil Cheon****, \\ Taehoon Chun***** and Inho Choi*,** \\ School of Biotechnology, Yeungnam University*, Bovine Genome Resources Bank**, Department of Biochemistry and \\ Molecular Biology, Eulji University***, Department of Biology, Sungshin Women's University****, \\ School of Life Sciences and Biotechnology, Korea University*****
}

\begin{abstract}
The research has been aimed to investigate the effect of different sera including fetal bovine serum (FBS), male bovine serum (MS), female bovine serum(FS), and castrated-male bovine serum (C-MS) on cell proliferation, follicular maturation and ovulation in vitro. Established cell lines and primary cells were cultured in the culture media supplemented with different sera and cells proliferation was observed by cell counting and MTT assay. The results indicated that cell proliferation was significantly different for different serum source. Proliferation of bovine and human myogenic satellite cells was highest in MS. In contrast, proliferation of breast cancer cells and immune cells were the highest in FS and FBS, respectively. There was no difference in the rate of follicular growth, whereas the rate of ovulation was higher in FBS and C-MS. Finally, the wound healing effect and cell proliferation of 3T3-L1 cells showed that wound healing was fastest in FS and cell proliferation was higher in MS. These results suggest the importance of an optimal serum selection in the experiments involving cell culture system, and gender-specific Hanwoo sera may be used as a substitute to FBS.
\end{abstract}

(Key words : Bovine serum, Proliferation, MTT assay)

\section{I. 서 론}

20세기 초 Carrel 등에 의해 세포배양이 처음 시도된 이 후 오늘에 이르고 있다. 일반적으로 세포배양기술은 동물 의 체액인 혈청을 첨가한 영양성분의 혼합물을 사용하고 있다. 혈청은 여러 가지 물질이 혼합된 복합물이며, 이중 에는 성장인자 (growth factor), 호르몬 및 세포를 자극하는 성분 등이 포함되어 있다(Ham와 Mckeenham, 1980). 특히, 성장인자들은 autocrine과 paracrine 작용을 통해 세포의 증 식과 분화에 영향을 주는 것으로 알려져 있다(Goustin 등, 1986; Sporn 등, 1987; Florini 등, 1991). 배양액에 첨가되 는 혈청은 실험목적에 따라 다양한 동물의 혈청이 세포배 양에 사용되고 있으나 일반적으로 FBS (소태아혈청: fetal bovine serum)를 가장 많이 사용하고 있다(Johnston와
Siegel, 1990). FBS는 임신기간 중에 송아지의 탯줄혈액으 로부터 분리되는 혈청으로, 여러 가지 영양소와 성장인자 를 포함하기 때문에 세포 배양액의 중요한 기본 구성물 중의 하나이다(Skottman와 Hovatta, 2006). 또한 소의 혈청 에서 추출된 알부민(albumin)은 제약 과정에서 약품의 안 정화를 위하여 사용되기도 하며, 생명과학분야의 실험에 서도 매우 광범위하게 이용되고 있다(Buttler, 2005). 현재 상용화 되고 있는 소 혈청은 FBS, newborn calf serum, normal bovine serum, donor bovine serum 등 여러 등급으 로 구분되어 세포 배양용으로 판매되고 있으며, 연구용 또는 제약 산업용으로 사용되는 소 혈액 제제의 시장 규 모는 최근까지 꾸준하게 증가 추세를 보이고 있다. 최근 발표된 소 혈액제제의 시장 규모에 대한 자세한 자료는 없지만, 2003년도 미국에서 세포배양에 사용되는 배양액, 
혈청 및 시약의 시장 조사를 보면, 세포 배양에 사용되는 소 혈청은 2008년도에만 약 3억5,000만 달러 (약 4,550억 원)로 추정되었으며 이러한 규모는 지속적으로 증가할 것 으로 예상된다(Shahani, 2003). 국내의 소 혈액 제제의 시 장 규모는 미국과 비교하면 미미한 정도로 미국 시장의 약 $2 \%$ 정도로 추정되고 있다. 2008년도에 국내 시장으로 수입·유통되는 세포배양용 혈청은 약 90 억 원 정도로 추 산된다.

2008년 농림수산부 자료에 따르면 국내 도축되는 소의 전체 두수는 769,432 두 (암소; 263,983두, 수소; 325,299두, 거세 수소; 180,150 두)이며 도축 후 방출되는 혈액은 수질 을 오염시킬 수 있는 환경호르몬의 주범으로 작용하고 있 다. 또한 1990년 Nijweide와 Burger 등의 발표에 따르면 $\mathrm{FBS}$ 로 배양된 세포를 임상적으로 사용할 경우 광우병 등 의 전염성 질환을 인간에 전파시킬 수 있는 잠재적 위험 성이 있다고 하였다. 이러한 이유로 광우병과 같은 전염 성 질병이 발생할 때마다 $\mathrm{FBS}$ 의 국내 반입이 금지되어 수입지연 및 가격상승을 초래하여 국내 많은 연구자들을 어렵게 하고 있어 이에 대한 대책이 시급하다. 또한 국내 소 혈청 제조는 외국에서 원료를 수입하여 판매하고 있으 며 혈청 생산의 산업기반이 전무한 실정이다.

따라서 본 연구는 도체 후 폐기되는 성체우의 암소, 수 소, 거세 수소혈액을 이용하여 혈청을 분리·정제하고, 이 를 이용하여 세포의 증식에 미치는 영향을 조사하였다. 본 연구의 결과를 바탕으로 도축 시 폐기되는 소 혈액부 산물을 산업화하고, 환경호르몬을 경감하는 친환경 녹색 성장 기술의 모델을 제공할 수 있을 것으로 사료된다.

\section{ㅍ. 재료 및 방법}

\section{1. 공시재료 및 혈청분리}

혈액 채취는 (주) 삼세 도축장 (경상북도 영천시)에서 도 축한 소 (암컷; 3 4세, 수컷; 2세, 거세 수컷; 2세)를 각각 3 마리씩 공시하였다. 소의 혈청을 분리하기 위하여 멸균 된 통에 혈액을 받고 $4^{\circ} \mathrm{C}$ 에서 $4 \sim 5$ 시간 정치 후 $5,000 \mathrm{rpm}$ 에서 20 분 동안 원심분리 하여 $4^{\circ} \mathrm{C}$ 에서 24 시간 정체한 후 상층액을 회수하여 $-20^{\circ} \mathrm{C}$ 에 급속 동결하였다. 동결된 혈 액을 다시 녹인 후 $7,000 \mathrm{rpm}$ 에서 20 분간 원심분리하고, 상 층액을 회수하여 $56^{\circ} \mathrm{C}$ 에서 30 분 동안 혈청내의 보체계 (열 에 불안정한 후천성 면역 성분)를 불활성화시키기 위하여 열비활성화 시킨 후 $0.22 \mu \mathrm{m}$ 여과기를 이용하여 제균하였 다. 여과 된 혈청은 사용 시까지 $-20^{\circ} \mathrm{C}$ 에 보관하였다.

\section{2. 세균학적 검사}

세균학적 검사는 Cappuccino와 Sherman(1987)의 방법을 이용하여 실시하였다. Ampicillin을 첨가하지 않은 멸균된 Luria-Bertani(LB) agar plate에 대조구는 손가락을 agar plate 위에 찍고, 처리구는 분리된 혈청을 $1 \mathrm{ml}$ 씩 분주하였 다. 처리가 끝난 $\mathrm{LB}$ agar plate를 $37^{\circ} \mathrm{C}$ 에서 24 시간 동안 배 양하였다. 배양한 후 각 그룹의 LB agar plate위에 생성된 세균 군집 (colony)의 유-무를 확인하였다.

\section{3. 세포주 및 세포배양}

본 연구에는 수술 후에 조직에서 분리한 사람 근육위성 세포와 유방암세포, 도축 후에 분리한 소 근육위성세포와 돼지 정소간질세포, 한국 세포주은행에서 분양 받은 MCF7세포, MDA-MB-231 세포와 3T3-L1 세포를 사용하였다. 생쥐 B lymphocyte 세포주(cell line)인 A20 (TIB-208), Chinese hamster ovary cell (CHO, CCL-61), 인간 T lymphocyte 세포주인 Jurkat (TIB-152), Chinese hamster ovary cell (CHO, CCL-61)은 ATCC (USA)에서 분양 받아 실험에 사용하였고, RMA 세포는 생쥐 T lymphocyte 세포 주로 실험실에서 유지하는 것을 사용하였다. 세포 배양은 FBS (Fetal bovine serum, Hyclone, USA)을 함유한 DMEM (Dulbecco,s modified Eagle,s media, Gibco BRL, Grand Island, NY, USA) 또는 RPMI (Rosewell Park Memorial Institue, Invitrogen, Breda, Netherland) 배지에서 $37^{\circ} \mathrm{C}, 5 \%$ $\mathrm{CO}_{2}$ 조건에서 배양하였다.

\section{4. 증식능의 측정}

$10 \% \mathrm{FBS}$ 를 첨가하여 배양한 세포를 대조구로 하여, 각 각 $10 \%$ FS (female bovine serum), MS (male bovine serum), C-MS (castrated-male bovine serum)가 첨가된 배양액에서 배양한 세포를 처리구로 두고 3 일간 각각의 배지에서 세 포를 배양하였다. 이후 hemocytometer를 이용하여 세포의 수를 측정하고, MTT assay 방법을 이용하여 증식율을 확 인하였다.

\section{(1) Hemocytometer에 의한 세포 수 측정}

$\mathrm{DMEM}$ 또는 RPMI에 $10 \% \mathrm{FBS}$ 가 첨가된 6-well plate에 $1 \times 10^{5} \mathrm{cell} / \mathrm{well}$ 의 세포를 넣고 세포의 안정화를 위하여 2 시간 동안 배양하였다. 그 후 $10 \% \mathrm{FBS}, \mathrm{FS}, \mathrm{MS}, \mathrm{C}-\mathrm{MS}$ 가 각각 첨가된 배양액으로 교체하고 72 시간 동안 배양하였 다. 배양 후 $0.25 \%$ trypsin-EDTA (Gibco BRL, Grand Island, $\mathrm{NY}, \mathrm{USA})$ 를 처리하여 세포를 부유시킨 다음 회수된 세포 를 hemocytometer를 이용하여 세포 수를 측정하였다.

(2) 세포증식측정 (MTT assay) 
생쥐 B lymphocyte 세포주인 A20, 인간 T lymphocyte 세 포주인 Jurkat, 생쥐 T lymphocyte 세포주인 RMA 세포 및 Chinese hamster ovary cell $(\mathrm{CHO})$ 를 3일 동안 서로 다른 혈 청에서 배양 한 후 MTT assay 방법을 이용하여 세포증식 율을 측정하였다. 이 때 사용되어진 세포의 농도는 $1 \times$ $10^{5} \mathrm{cell} / \mathrm{well}$ 로 조정하여 96-well plate에서 측정하였다. MTT assay는 세포의 증식을 정확하게 측정할 수 있는 기 법으로, 원리는 미토콘드리아 내 탈수소 효소의 활성이 왕성하게 되면 노란색의 수용성 기질인 MTT tetrazolium (Sigma Chemical Co., St. Louis, Mo, USA)을 청자색을 띄 는 비수용성의 MTT formazan [3-(4,5-dimethylthiazol-2-yl)2,5-diphenyl-tetrazolium bromide]으로 환원시키는 미토콘드 리아의 능력을 이용하는 검사법이며, $540 \mathrm{~nm}$ 파장에서 흡 광도를 측정하였다.

\section{5. 난포분리와 배양}

혈청에 따른 난포의 체외성숙과 배란을 연구하기 위하 여 Wycherley 등 (2004)의 방법을 이용하여 난포를 분리하 고 배양하였다. 간단히 설명하면, 생후 21 22일된 암컷 생 쥐 (CD-1 strain)에 $5 \mathrm{IU}$ 의 Pregnant Mares Serum Gonadotropin (PMSG; PEAMEX, Sanky Zolki, Tokyo, Japan)를 복강에 주 사하고 12시간 후에 난소를 떼어 현미경하(Olympus, IX70 series)에서 지방조직 및 다른 혈액응고성분들을 완전히 제 거한 후에 N-2-hydroxyethylpeperazine-N-2-ethanmesulphonic acid (HEPES; Sigma Chemical Co., St. Louis, USA)를 첨가 한 배양액이 있는 시계접시에 옮겼다. 현미경하에서 두 개의 날카로운 바늘을 이용하여 난소에서 직경 240 300 $\mathrm{mm}$ 의 난포만을 분리시켰다. 분리된 난포는 96-well roundbottom plate에 $100 \mu l$ 의 drop에 배양하였다. 배양액은 aminimal essential medium(a-MEM)에 5\% FBSs (heat inactivated), $5 \mathrm{IU} / \mathrm{ml}$ human follicle stimulating hormone (FSH: SigmaAldrich), $\quad 10 \mathrm{mg} / \mathrm{ml} \quad$ transferring (Sigma-Aldrich), $\quad 5 \mathrm{mg} / \mathrm{ml}$ insulin (Sigma-Aldrich), $2.5 \mathrm{ng} / \mathrm{ml}$ sodium selenite (SigmaAldrich), and $25 \mathrm{mg} / \mathrm{ml}$ ascorbic acid (Sigma-Aldrich)를 첨가 하여 사용하였다. 배란 유도는 $1 \mathrm{IU} / \mathrm{ml}$ human hCG (Sigma-Aldrich)를 배양액에 첨가하고 24시간 동안 배양하 였다. 난포의 크기와 지름은 위상차 현미경으로 측정하였 다. 한편 난포의 배란은 $\mathrm{hCG}$ 처리 후 24 시간에 세포배양 현미경 (Lize)하에서 숫자를 측정하였다.

\section{6. 창상 치유 (Wound Healing)}

창상 제작은 6-well plate에 배양된 3T3-L1 세포가 증식 하여 well 표면에 80 90\% 밀생하게 되었을 때 Miyata 등 (1990)이 고안한 직경 $1 \mathrm{~mm}$ 의 silicone tip을 이용하여 well
의 한 가운데에서 3T3-L1 세포와 살짝 접촉시킴으로써 찰 과를 일으켜 창상을 만들었다. 창상을 만든 직후에 $10 \%$ $\mathrm{FBS}, \mathrm{FS}, \mathrm{MS}, \mathrm{C}-\mathrm{MS}$ 가 첨가된 배양액을 넣고 18 시간 배양 후 도립위상차 현미경 (Nikon)으로 사진촬영을 하고 관찰 하였다.

\section{7. 통계 처리}

본 연구에서 얻은 결과는 mean $\pm \mathrm{SD}$ 로 표시하였으며, 대조구와 혈청에 대한 결과 비교는 Dunnett's test 방법을 이용하여 유의성 검정 $(* \mathrm{P}<0.05, * * \mathrm{P}<0.01, * * * \mathrm{P}<0.001)$ 을 실시하였다.

\section{III. 결과 및 고찰}

\section{1. 세균학적 검사}

혈청에 대한 세균학적 검사 결과 대조구에서 다량의 박 테리아 군집 (bacteria colony)이 발견되었고 혈청 처리구에 서는 박테리아 군집이 전혀 나타나지 않았다 (Fig. 1). 따 라서 본 연구에서 분리 정제한 혈청은 세균에 오염되지 않았고, 세포배양 시 배양액 첨가제로 적합한 것으로 사 료된다.

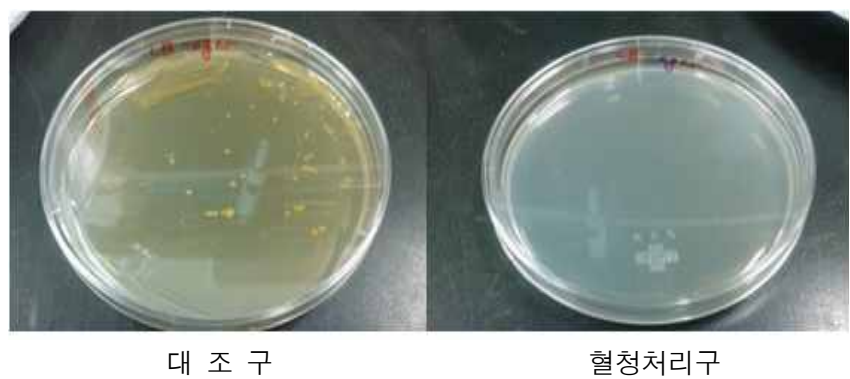

Fig. 1. Evaluation of bacteriological security in bovine serum.

Cultivation was carried out for $72 \mathrm{hrs}$ at $37^{\circ} \mathrm{C}, 5 \% \mathrm{CO}_{2}$ in a LB agar plate (without antibiotic).

\section{2. 혈청이 일반 세포배양에 미치는 영향}

혈청이 일반세포의 성장에 미치는 효과를 알아보기 위 해 $\mathrm{FBS}, \mathrm{FS}, \mathrm{MS}, \mathrm{C}-\mathrm{MS}$ 를 각각 $10 \%$ 씩 배양액에 첨가하여 배양한 결과 (Fig. 2) 세포증식률은 처리구들이 대조구에 비해 초기배양 세포(소 근육위성세포, 사람근육위성세포, 유방암)와 세포주인 MDA-MB-231 세포는 통계학적으로 유의성 있게 높게 나타났다 $(\mathrm{P}<0.001)$. 근육위성세포의 경 우 $\mathrm{MS}$ 에서 높은 증식률을 보였으며, $\mathrm{FS}$ 에서는 유방암 세 


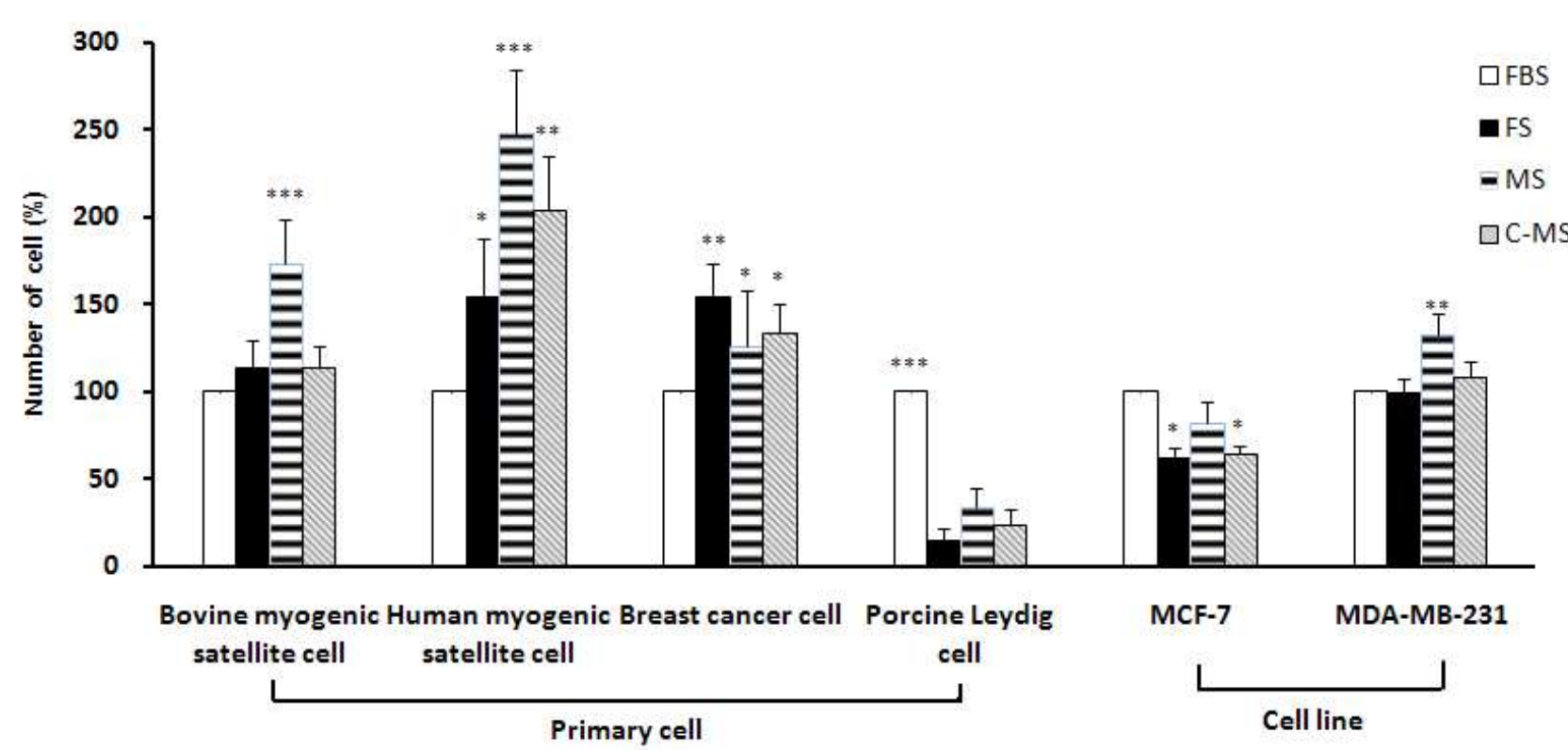

Fig. 2. Effect of bovine sera on proliferation of primary cells and established cell lines.

Percentage of different cells grown under different serum condition, fetal bovine serum (FBS), bovine female serum (FS), male serum (MS) and castrated-male serum (C-MS) were calculated considering number of cells in FBS supplement culture as $100 \%$. Proliferation of cells was determined by direct cell counting using a hemocytometer for the 3 days after plating. Data represent mean \pm SEM of 3 separate experimental replicates $\left(* \mathrm{P}<0.05,{ }^{* *} \mathrm{P}<0.01,{ }^{* * *} \mathrm{P}<0.001\right)$.

포에서 높은 증식률을 보였다. 특히 근육위성세포의 성장 률은 배양액의 차이보다 혈청의 종류에 따라 성장률을 다 르게 나타낼 수 있다는 선과 명 (2000)의 보고와 유사하다. 이러한 혈청에 의한 성장률의 변화는 아직 명확하지 않지 만 혈청 내에 존재하는 미지성장인자들에 의하여 영향을 받는다고 하였다. 돼지 정소간질세포와 MCF-7 세포의 세 포증식률이 통계학적으로 유의성 있게 낮았다. 일반적으 로 혈청은 동물세포 배양에서 성장을 지원하는 역할로 에 너지원이나 성장촉진인자의 공급원으로 많이 사용되고 있 으며 많은 단백질과 호르몬 등이 중요한 역할을 한 것으 로 보고하고 있다(Ham와 Mckeeham, 1980). 본 연구에서 이용한 혈청의 경우 스테로이드 호르몬 (testosterone, 17ßestradiol, estrone) 농도 측정 결과 대조구 혈청에 비해 스 테로이드 농도가 높게 측정 되었으며 (data not shown), 이 는 스테로이드 호르몬이 세포 성장에 중요한 역할을 하는 것으로 사료된다 (Chittaranjan 등, 2009).

\section{3. 혈청이 면역 세포배양에 미치는 영향}

$\mathrm{A} 20$, Jurkat, $\mathrm{CHO}$ 세포에서는 대조구보다 처리구에서 유의적으로 낮은 증식률을 보였으며 $(\mathrm{P}<0.01), \mathrm{RMA}$ 세포 에서는 혈청간의 큰 차이를 보이지 않았다 (Fig. 3). Matsuzki 등 (1988)은 노화에 따른 T세포 기능의 퇴화는 T

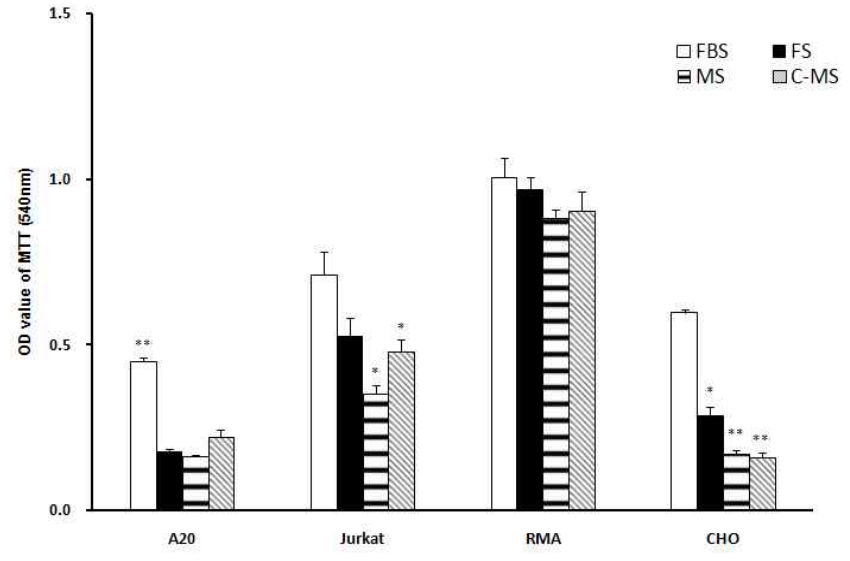

Fig. 3. Effect of the different sera on immune cells proliferation.

Proliferation of cell grown in the media supplemented with FS, MS, C-MS and FBS were determined by MTT assay after 4 days of cell plating. The optical density (O.D.) for the cells cultured in FBS supplemented media was considered as control. Data represent mean \pm SEM of three different experiments $\left({ }^{*} \mathrm{P}<0.05,{ }^{* *} \mathrm{P}<0.01\right)$.

세포 subpopulation 변화의 원인이 있다고 주장하였다. T세 포의 기능저하는 mitogen에 대한 분열 증식반응, 여러 가 지 항원에 대한 $\mathrm{T}$ 세포 의존성항체반응의 저하를 나타낸 다. 따라서 본 연구에 사용된 성체 혈청은 노화에 따른 면역능력의 저하(Immuno-senescence)로 면역세포 분열에 영향을 미치는 것으로 사료된다. 


\section{4. 혈청이 난포의 성장 및 배란에 미치는 영향}

배양액에 첨가된 혈청이 난포의 성장과 배란에 미치는 영향은 Fig. 4와 같다. 혈청에 따른 난포성장의 차이는 통 계학적인 유의성을 보이지 않았으나 사용한 혈청 간 차이 가 형성되었다(Fig. 4A). 배란은 대조구와 처리구 사이의 통계학적인 유의성을 보이며 $(\mathrm{P}<0.05), \mathrm{FBS}$ 와 $\mathrm{C}-\mathrm{MS}$ 가 첨 가된 배양액에서 배란이 잘 일어났다(Fig. 4B). 각 구간 배란율의 차이는 상대적 성장률이 높은 구에서 유의하게 높게 나타났다. 이러한 결과는 초기 난포의 체외 배양 시 에는 적절한 조절인자를 첨가한 배양 조건이 중요하며 난 자와 과립세포가 상호작용을 활발히 하여 난자의 성장과 더불어 과립세포가 발달하고 증식하게 될 때 정상적인 난 포발달이 일어나게 된다(박 등, 1991). 소의 난포 과립세 포는 배양액내에 혈청성분이 없으면 세포자연사를 진행한 다고 하였다 (Hu 등, 2001). 박 등 (2001)은 마우스 난포의 체외성장에 $\mathrm{FBS}$ 를 배양액에 첨가하여 효과적으로 체외성 장을 시켰다고 보고하였다. 흥미롭게도 본 연구의 결과에 서 알 수 있듯이 세계적으로 상용되는 $\mathrm{FBS}$ 와 비슷하게 C-MS가 난포의 성장과 배란을 돕는 연구결과를 얻을 수 있었다. 흥미롭게도 난소에서 유래한 $\mathrm{CHO}$ 세포주의 경우 $\mathrm{FBS}$ 에 의한 세포증식이 매우 활발하였으나 실험에서 사 용된 다른 혈청에서는 반응을 유도하지 못하였다. 혈중 난포의 성장과 $\mathrm{E}_{2}$ 의 농도는 비례관계이나 난포 액에서 $\mathrm{E}_{2}$ 농도가 높으면 배란을 억제한다 (Appasamy 등, 2008). 한편 난포는 여러 난포막세포, 과립세포, 난자 등 여러 세포군 이 복합적으로 존재하여 호르몬에 대한 반응성이 서로 다
르다. 따라서 C-MS가 난포의 성장과 배란에 있어서 $\mathrm{E}_{2}$ 가 낮은 $\mathrm{FBS}$ 와 $\mathrm{C}-\mathrm{MS}$ 에서 배란율이 유의적으로 높게 나타난 것으로 분석된다. 이러한 결과를 바탕으로 혈청의 유래에 따른 이용 가능성이 높음을 알 수 있다.

\section{5. 혈청이 창상치유 및 지방세포에 미치는 영향}

3T3-L1 세포를 이용하여 각 혈청이 창상치유와 세포 증 식율에 미치는 영향을 관찰하였다. 창상 제작 후 창상이 치유되는 동안 창상의 가장자리에 있는 세포는 창상의 중 앙을 향해 그 모양이 길어지고 방추형으로 변하였고 그 주위의 세포는 다각형이었다. 대조구에 비해 처리구에서 치유속도가 빨라지는 것이 관찰되었다(Fig. 5A). 세포 증 식율은 대조구에 비해 처리구에서 모두 높게 나타났으며 (Fig. 5B), 특히 MS와 FS는 통계적으로 유의성이 있게 높 았다 $(\mathrm{P}<0.001)$. Roncari 등 (1978)은 배양중인 사람 지방세 포에 에스트로겐을 처리했을 때 지방세포의 증식을 촉진 했다고 보고하였다. 그리고 김 등 (2007)은 세포배양 전기 에 스테로이드 성호르몬을 처리했을 때 지방전구세포의 분화나 증식에 아무런 영향을 미치지 않은 반면, 세포배 양 후기에 테스토스테론과 노르테스토테론을 처리하면 세 포분화를 촉진하였다고 보고하였다. 본 연구에서 FBS 보 다 스테로이드 호르몬이 많이 들어있는 $\mathrm{FS}$ 에서는 증식속 도가 가장 빨리 진행되었으며, $\mathrm{MS}$ 에서는 세포수가 가장 많이 증가되는 것을 관찰하였다. 소 혈청에 의한 3T3-L1 세포의 증식과 migration 속도의 증가는 PPAR, integrin, 그 리고 다양한 extracellular-matrix 단백질과 같은 세포 증식
【A】

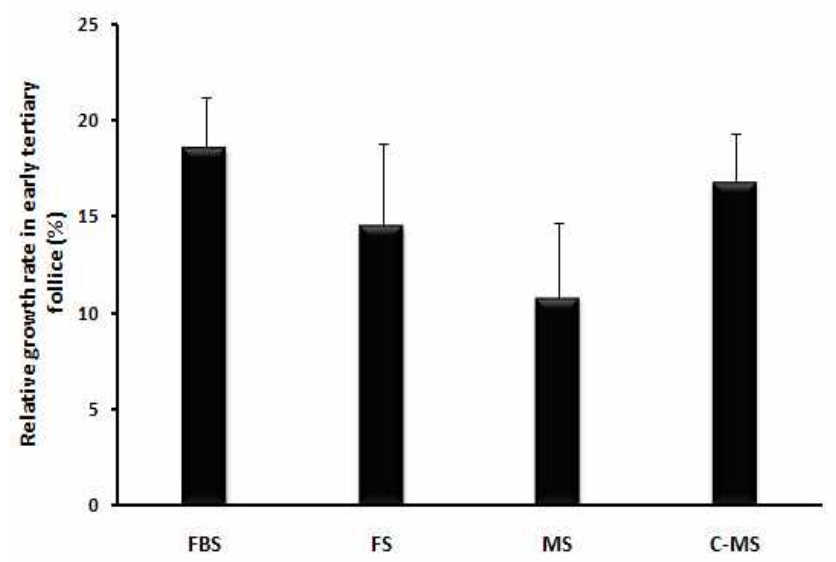

[B]

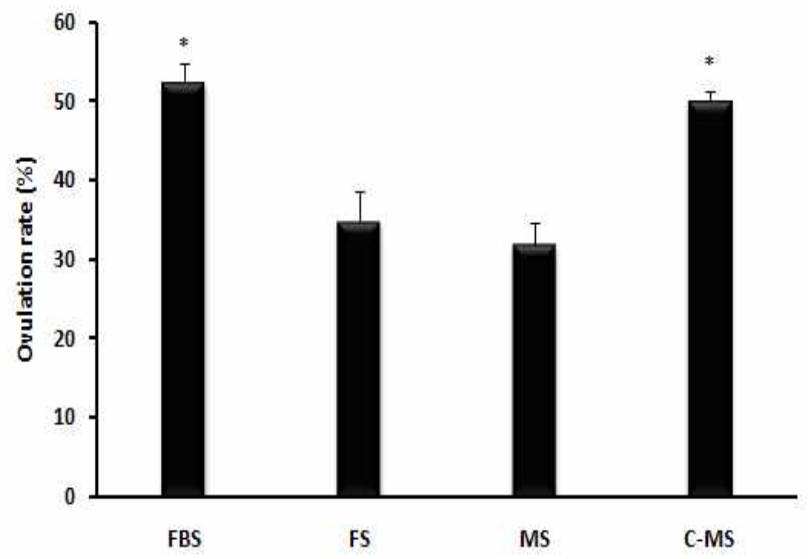

Fig. 4. Follicular maturation and ovulation in the media supplemented with FBS, FS, MS and C-MS

Follicles at early tertiary stage were isolated and cultured in the media containing the different serums for 58 hrs. Relative growth of follicles (A) and ovulation (B) were checked. Data represent mean \pm SEM of three different experiments $(* \mathrm{P}<0.05)$. 
【A】

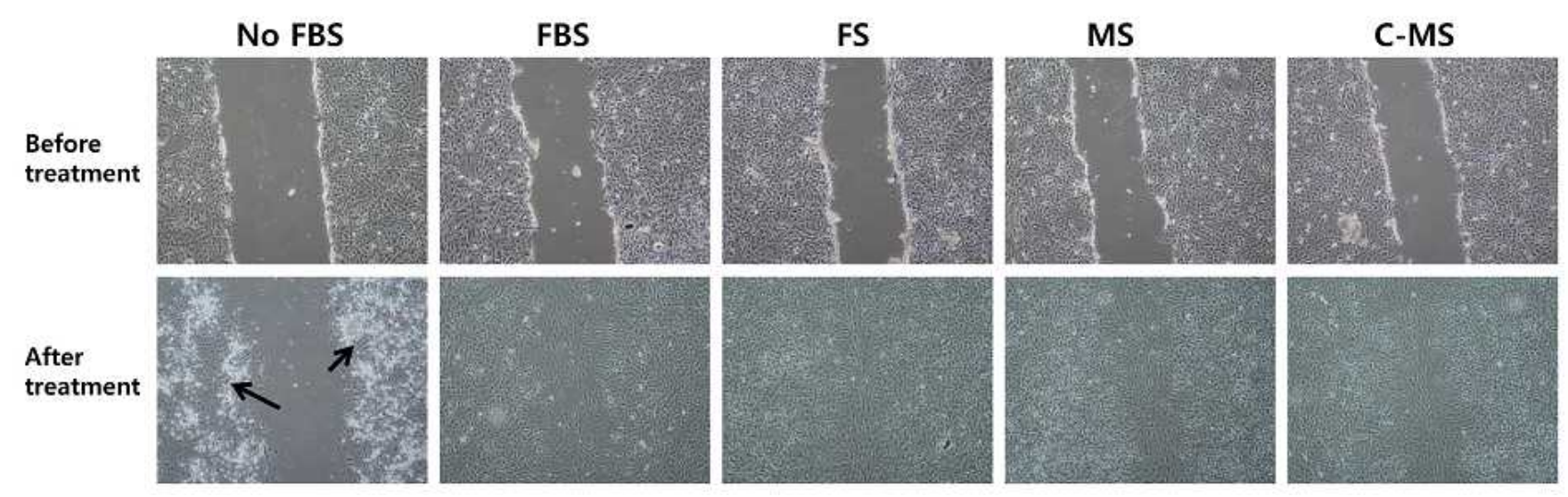

【B】

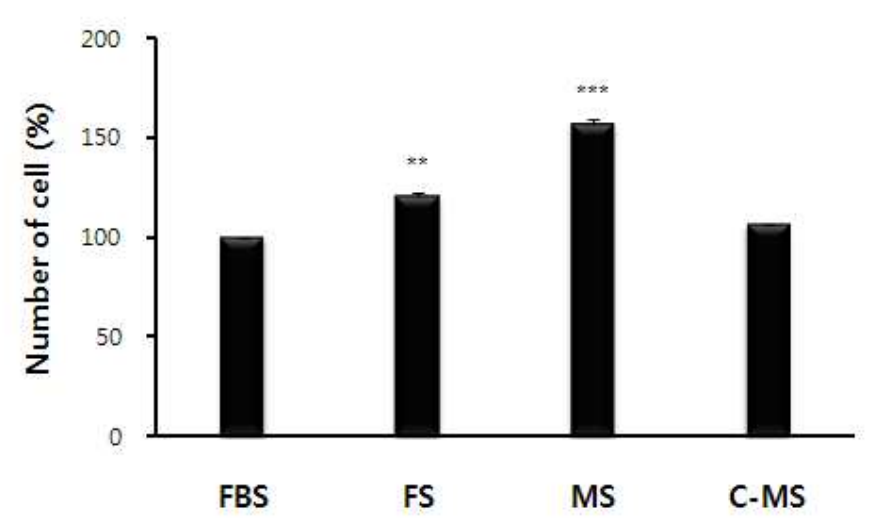

Fig. 5. Effect of sera on wound healing and proliferation of 3T3-L1 cells.

For wound healing method, 3T3-L1 cells were cultured for 18 hours in media supplemented with FBS, FS, MS and C-MS prior to which a line of cells were scratched and allowed to grow to fill up the space. Arrows indicate clumps of dead cells, which were caused by absence of FBS in culture medium(A). Proliferation of cells grown under bovine FS, MS, C-MS and FBS for the 3 days after plating was determined by using a hemocytometer. Percentage of cells was calculated considering number of cells in FBS supplement culture as $100 \%$ (B). Data represent mean \pm SEM of three different experiments $(* * \mathrm{P}<0.01$, $* * * \mathrm{P}<0.001$ ).

과 migration에 관여하는 유전자의 발현 증가에 의해 이루 어지는 것으로 유추되며, 추가적으로 유전자 발현 변화에 대한 관찰이 필요할 것으로 여겨진다.

이상의 결과를 종합하면, 성별 특이 소 혈청을 배양액 에 첨가하여 세포 배양에 미치는 영향은 세포의 종류에 따라 차이가 있으며, 근육위성세포와 지방세포에서는 한 우에서 분리한 혈청이 FBS 보다 우수하여 대체할 수 있 을 것으로 사료된다.

또한 지속적인 연구를 통하여 가축의 도체부산물을 활 용하여 고부가 혈청을 개발하여 산업화 할 경우 저렴한 가격의 혈청, 원활한 공급, 연구자의 연구목적에 맞게 사 용할 수 있는 맞춤형 혈청을 통해 생명공학 산업 발전에 일익을 담당할 수 있을 것으로 판단된다.

\section{IV. 요 약}

본 연구는 성체우의 $\mathrm{FS}, \mathrm{MS}, \mathrm{C}-\mathrm{MS}$ 를 배양액에 첨가하 여 세포증식과 난포의 성장과 배란에 미치는 영향을 관찰 하기 위하여 실시하였다. 세포증식은 세포수와 MTT assay 을 실시하여 확인하였다. 그 결과 세포증식은 혈청첨가 배양액에 따라 유의적인 차이를 나타내었다. 특히 근육위 성세포의 세포증식은 $\mathrm{MS}$ 를 첨가한 배양액에서 높은 반면 면역세포의 증식은 $\mathrm{FBS}$ 에서 배양한 세포에 비해 낮은 것 을 확인하였다. 또한 난포의 성장 및 배란을 관찰한 결과 난포의 성장에 유의한 차이가 없었으나 군간 차이를 보였 으며 배란율과 비례적이었고, 배란율은 $\mathrm{FBS}$ 와 C-MS가 첨 가된 배양액에서 유의적으로 높은 것을 관찰할 수 있었다 $(\mathrm{P}<0.05)$. FBS군과 $\mathrm{C}-\mathrm{MS}$ 군 간에는 차이가 없었다. 3T3- 
$\mathrm{L} 1$ 세포에서 창상치유는 $\mathrm{FS}$ 에서 배양한 세포에서 빠른 회 복을 나타냈으며, 증식은 $\mathrm{MS}$ 에서 높게 나타났다 $(\mathrm{p}<0.001)$. 따라서 본 결과는 세포배양 과정에서 세포에 따른 혈청의 선택은 매우 중요하다는 근거자료를 제시 하였으며, 분리 된 성별 특이 한우 혈청은 $\mathrm{FBS}$ 의 대체 물질로서 사용이 가능할 것으로 사료된다.

$$
\mathrm{V} \text {. 사 사 }
$$

본 연구는 2009년도 정부(교육과학기술부)의 재원으로 한국과학재단의 지원(2009-0060480)을 받아 수행되었다. 원고의 교정에 도움을 주신 건국대학교 수의과대학 남상 섭 교수님과 영남대학교 생명공학부 프리티바즈라촤리여 님께 진심으로 감사 드립니다. 본 연구에 사용한 한우 혈 청 및 한우 근육세포는 소유전체연구 소재은행에서 소장 하고 있는 것을 사용하였다.

\section{VI. 인 용 문 헌}

1. Appasamy, M., Jauniaux, E., Serhal P., Al-Qahtani, A., Groome, NP. and Muttukrishna, S. 2008. Evaluation of the relationship between follicular fluid oxidative stress, ovarian hormones, and response to gonadotropin stimulation. Fertil Steril. 89:912-921.

2. Butler, M. 2005. Animal cell cultures: recent achievements and perspectives in the production of biopharmaceuticals. Appl Microbiol Biotechnol. 68:283-291.

3. Cappuccino, JG. and Sherman, N. 1987. Microbiology, A laboratory manual, 2nd Ed., 52-80.

4. Carrel, A. and Burrows, MT. 1911. Cultivation of tissues in vitro and its technique. J. Exp. Med. 13:387.

5. Chittaranjan, S., McConechy, M., Hou, YC., Freeman, JD., Devorkin, L. and Gorski, SM. 2009. Steroid hormone control of cell death and cell survival: molecular insights using RNAi. PLoS Genet. 5:e1000379.

6. Florini, JR., Ewton, DZ. and Magri, KA. 1991. Hormones, growth factors, and myogenic differentiation. Annu Rev Physiol. 53: 201-216.

7. Goustin, AS., Leof, EB., Shipley, GD. and Moses, HL. 1986. Growth factors and cancer. Cancer Res. 46:1015-1029.

8. Ham, GR. and Mckeeham, WL. 1980. In vitro cell. Decelop. Biol., 14:11.

9. Ham, RG. 1965. Clonal growth of mammalian cells in a chemically defined, synthetic medium. Proc Natl Acad Sci U S A. 53:288-293
10. Hu, CL, Cowan, RG., Harman, RM., Porter, DA. and Quirk, SM. 2001. Apoptosis of bovine granulosa cells after serum withdrawal is mediated by Fas antigen (CD95) and Fas ligand. Biol Reprod. 64:518-526.

11. Johnston, S. and Siegel, C. 1990. Comparison of a serum replacement (Omni Serum) and fetal bovine serum in cell cultures used to isolate herpes simplex virus from clinical specimens. J Clin Microbiol. 28:643-645.

12. Kärre, K., Ljunggren, H. G., Piontek, G. and Kiessling, R. 1986. Selective rejection of H-2-deficient lymphoma variants suggests alternative immune defence strategy. Nature 319:675678.

13. Kim, KJ., Kanellopoulos-Langevin, C., Merwin, RM., Sachs, DH. and Asofsky, R. 1979. Establishment and characterization of BALB/c lymphoma lines with B cell properties. J Immunol. 122:549-554

14. Matsuzaki, G., Yoshikai, Y., Kishihara, K., Nomoto, K., Yokokura, T. and Nomoto, K. 1988. Age-associated increase in the expression of $\mathrm{T}$ cell antigen receptor gamma chain genes in mice. Eur J Immunol. 18:1779-1784.

15. Miyata, K., Murao, M., Sawa, M. and Tanishima, T. 1990. New wound-healing model using cultured corneal endothelial cells. 1. Quantitative study of healing process. Jpn J. Ophthalmol. 34:257-266.

16. Mosmann, T. 1983. Rapid colorimetric assay for cellular growth and survival: application to proliferation and cytotoxicity assays. J Immunol Methods. 65:55-63.

17. Nijweide, PJ. and Burger, EH. 1990. Mechanisms of bone formation in vitro. In The osteoblast (Ed. B. K. Hall), Telford Press, Caldwell, New Jersey. 1:303.

18. Roncari, DA. and Van RL. 1978. Promotion of human adipocyte precursor replication by 17 beta-estradiol in culture. $\mathrm{J}$ Clin Invest. 62:503-508.

19. Shahani, S. 2003. The dynamic media, sera and reagent market in the cell culture industry. BCC Research. Report Code: BIO014D.

20. Skottman, H. and Hovatta, O. 2006. Culture conditions for human embryonic stem cells. Reproduction. 132:691-698.

21. Sporn, MB., Roberts, AB., Wakefield, LM. and de Crombrugghe, B. 1987. Some recent advances in the chemistry and biology of transforming growth factor-beta. J. Cell Biol. 105:1039.

22. Weiss, A., Wiskocil, RL. and Stobo, JD. 1984. The role of T3 surface molecules in the activation of human $\mathrm{T}$ cells: a two-stimulus requirement for IL 2 production reflects events occurring at a pre-translational level. J Immunol. 133:123-128.

23. Wycherley, G., Downey, D., Kane, MT. and Hynes, AC. 2004. 
A novel follicle culture system markedly increases follicle volume, cell number and oestradiol secretion. Reproduction. 127:669-677.

24. 김혜림, 이기호, 최인호, 정정수. 2007. 스테로이드 성호르몬 이 돼지 지방전구 세포의 분화에 미치는 영향. 한국동물자원 과학회지. 49:593-598.

25. 박기상, 김주환, 이택후, 송해범, 전상식. 2001. 호르몬 무첨 가 배양액에서 생쥐 Pre-antral Follicles의 체외 성장과 난포
강 형성. 대한불임학회지 28:79-86.

26. 박형배, 조경숙, 백청순, 김재명, 이선경, 서병희, 이재현. 1991. 체외수정시 난포액 내 Steroid 호르몬 동태에 관한 연 구. 대한산부인과학회지. 34:537-554.

27. 선상수, 명규호 2000. 한우와 홀스타인 비육우의 근육 위성 세포 Cloning 및 배양. 한국동물자원과학회. 42:787-794. (접수일자 : 2009. 9. 3. / 수정일자 :2009. 10. 15. / 채택일자 : 2009. 10. 16.) 